\title{
PENGUKURAN OVITRAP INDEX (OI) SEBAGAI GAMBARAN KEPADATAN NYAMUK DI DAERAH ENDEMIS DEMAM BERDARAH DENGUE (DBD) KABUPATEN BANYUMAS
}

\author{
Siwi Pramatama Mars Wijayanti., Dian Anandari., Arrum Firda Ayu Maqfiroch \\ Jurusan Kesehatan Masyarakat, Fakultas Ilmu-ilmu Kesehatan \\ Universitas Jenderal Soedirman
}

\begin{abstract}
ABSTRAK
Kepadatan nyamuk bisa memprediksi risiko transmisi Dengue Virus (DENV) di daerah tertentu. Ovitrap Index (OI) adalah salah satu metode untuk mengukur kepadatan nyamuk disamping metode lain seperti Indeks Stegomyia dan indeks larva bebas. Indeks ovitrap lebih murah, lebih appliacable dan sensitif untuk mendeteksi aktivitas Aedes sp untuk bertelur di dinding kontainer. Tujuan penelitian ini untuk mengukur indeks ovitrap di daerah DENV endemik, mengetahui preferensi betina Aedes sp untuk bertelur, dan mengetahui hubungan antara kasus OI dan kasus demam berdarah di daerah DENV endemik. Jenis penelitian ini deskriptif dengan desain cross sectional. Wilayah studi di Puskesmas Purwokerto Timur II di Kranji, Sokanegara dan Purwokerto Lor. Ovitrap dipasang di 50 rumah dari masing-masing desa, dengan total ovitrap 100 di setiap desa. Setelah 6 hari pemasangan, ovistrips dikumpulkan dan telur dihitung. Indeks ovitrap di tiga desa diamati pada persentase lebih dari $50 \%$, dengan OI tertinggi terdeteksi di Desa Kranji $(97,56 \%)$. Wanita Aedes sp dipantau untuk bertelur di luar ruangan daripada di dalam ruangan. OI tidak selalu relevan untuk memprediksi kasus demam berdarah tetapi dapat menginformasikan risiko penyimpangan DENV di daerah tertentu. Masyarakat harus melakukan upaya untuk meminimalkan potensi tempat berkembang biak, terutama wadah yang tidak digunakan di luar ruangan untuk mengurangi kepadatan nyamuk.

Kata kunci : Ovitrap, Demam Berdarah, Kepadatan Nyamuk
\end{abstract}

\begin{abstract}
Mosquito density could predict the risk of Dengue Virus (DENV) transmission in certain area. Ovitrap Index (OI) is one of the methods to measure the mosquito density beside other methods such as Stegomyia Indices and free larvae index. Ovitrap index is cheaper, more appliacable and sensitive to detect Aedes sp activity to lay their eggs on the wall of container. The aims of this research were to measure ovitrap index in endemic DENV areas, to find out the preferences of female Aedes sp to lay their eggs, and find out the correlation between OI and dengue cases in endemic DENV areas. Type of this study was decriptive with cross sectional design. The area of study was in Community Health center Purwokerto Timur II in Kranji, Sokanegara and Purwokerto Lor. Ovitrap were installed at 50 houses of each vilagges (one indoor, one outdoor), with total ovitrap 100 in each villages. After 6 days of installation, ovistrips were collected and the eggs were counted. The Ovitrap index in three villages were observed at percentage more than 50\%, with the highest OI detected in Kranji Village (97.56\%). Female Aedes sp were monitored to lay their eggs outdoor than indoor. The OI is not always relevant to predict the dengue cases but could inform the risk of DENV tranmission in certain area. The community should do efforts to minimize potential breeding sites, mainly unused container outdoor to reduce the mosquito density.

Keyword : Ovitrap, Dengue, Mosquito density
\end{abstract}

\section{PENDAHULUAN}

Penyakit Demam Berdarah Dengue (DBD) masih terus menimbulkan masalah kesehatan di Indonesia dengan angka kasus yang terus terjadi di berbagai daerah.
Penyakit DBD disebabkan oleh virus dengue yang terdiri dari virus dengue serotipe 1, 2, 3, 4 dan 5 (Mustafa et al., 2015). Penularan virus dengue melalui gigitan nyamuk Aedes aegypti sebagai vektor utama dan vektor 
sekundernya yakni Aedes albopictus (Higa, 2011). Gejala klinisnya sebagian besar asimptomatik, tetapi bisa mengakibatkan manifestasi klinis yang parah seperti perdarahan dan juga sindrom syok (dengue shock syndrome/DSS) (Guzman et al., 2010). Sampai saat ini, karena penerapan vaksin DBD belum dilaksanakan, maka upaya pencegahan penularan DBD masih berfokus pada menekan populasi nyamuk yang menularkan virus dengue dengan gerakan Pemberantasan Sarang Nyamuk (PSN) (Pasteur, 2016).

Kepadatan populasi nyamuk di suatu daerah dapat menggambarkan potensi terjadinya penularan DBD. Salah satu cara yang bisa dilakukan yakni dengan mengukur ovitrap index (OI)nya (WHO, 1997). OI menggambarkan jumlah ovitrap yang positif telur dari sejumlah ovitrap yang diobservasi. OI ini menjadi cara menggambarkan aktivitas bertelur nyamuk dewasa baik di dalam maupun di luar rumah. Angka ini bisa untuk menambah informasi dari survey jentik seperti House Index (HI), Breteau Index (BI) dan Container Index (CI). Beberapa kelebihan penggunaan ovitrap antara lain ekonomis, spesifik dan sensitif. Ovitrap dapat dibuat dari barang-barang di sekitar kita seperti kaleng bekas (Norzahira et al., 2011). Surveillans untuk mengukur kepadatan nyamuk di beberapa penelitian juga menggunakan metode OI ini (Codeço et al., 2015; Norzahira et al., 2011; Wijayanti et al., 2016) . Data dari hasil ovitrap juga lebih sensitif dibandikan indeks traditional yang menggunakan Stegomyia index (Focks, 2003; WHO, 1997). Metode ovitrap juga dapat mendeteksi nyamuk dari tempat perindukan yang tidak terjangkau dan area di sekitarnya (de Resende et al., 2013). Kriteria OI terbagi menjadi 4 level tergantung persentase OI nya yakni level 1 (O.I. < 5\%), level $2(5 \% \leq$ O.I. $<20 \%)$, level $3(20 \% \leq$ O.I. $<40 \%)$ dan level 4 (O.I. $\geq 40 \%$ ) (FEHD, 2017).

Nyamuk betina dewasa biasanya akan meletakkan telurnya sekitar 50-500 telur di dinding kontainer sekitar 2-4 hari setelah adanya darah untuk pematangan telurnya. Telur dapat bertahan selama beberapa minggu sampai 1 bulan dan dapat menetas sebagai larva apabila sudah terpapar dengan air (Becker, 2010). Secara morfologi telur Aedes sp berukuran kecil, hitam, berbentuk oval (Christophers, 1960). Peletakkan telur Aedes $s p$ bisa dilakukan di dalam maupun di luar rumah. Penelitian untuk melihat kecenderungan nyamuk Aedes $s p$ dalam meletakkan telurnya juga menarik untuk dilakukan. Oleh karena itu peneliti tertarik untuk melakukan penelitian tentang 
pengukuran kepadatan nyamuk dengan ovitrap index, juga melihat kecenderungan bertelur nyamuk Aedes $s p$ di dalam atau di luar rumah. Penelitian ini juga akan mengidentifikasi spesies nyamuk yang ditemukan pada saat survey nyamuk.

Lokasi penelitian dilakukan di Puskesmas Purwokerto Timur sebagai puskesmas dengan angka kasus DBD yang tinggi di Kabupaten Banyumas. Kabupaten Banyumas merupakan salah satu kabupaten di Jawa Tengah dengan Incidence rate/IR 47,94 dan Case Fatality Rate/CFR 1,75 pada Tahun 2016 (Dinkes Banyumas, 2016). Angka tersebut masih jauh di atas target Nasional yaitu IR<20,00 dan CFR < 1\% (Dinkes Jateng, 2009). Pada Tahun 2016 angka kasus DBD di Kabupaten Banyumas mengalami peningkatan signifikan yakni 990 kasus, karena pada Tanggal 14 Februari sampai 31 Maret 2016 terjadi Kejadian Luar Biasa (KLB) DBD. Penelitian mengambil lokasi di Purwokerto Timur dan yakni Desa Kranji, Sokanegara dan Purwokerto Lor karena merupakan kawasan endemis DBD dengan angka kasus yang cukup tinggi.

\section{METODE}

Penelitian ini merupakan penelitian deskriptif dengan pendekatan cross sectional. Lokasi penelitian dilakukan di Puskesmas Purwokerto Timur II yakni di
Desa Kranji, Sokanegara dan Purwokerto lor. Ketiganya merupakan desa endemis DBD (desa dengan 3 tahun terakhir terdapat kasus DBD) yang ditetapkan oleh Dinas Kesehatan Kabupaten Banyumas. Pelaksanaan penelitian dilaksanakan pada Bulan Agustus-September 2016, dilakukan dengan pemasangan ovitrap sebanyak 50 rumah per desa (di dalam dan di luar rumah, dengan total 100 ovitrap per desa). Total keseluruhan ovitrap yang dipasang sejumlah 300 buah. Ovitrap dibuat dari $250 \mathrm{ml}$ kontainer plastik yang dicat hitam di bagian luarnya. Pada saat pemasangan, kontainer diisi 1/3nya dengan air dan filter paper diletakkan di sekeliling dinding permukaan dalam kontainer untuk tempat meletakkan telur bagi nyamuk. Setelah 6 hari pemasangan, ovitrap di ambil kemudian dilakukan penghitungan telur. Ovitrap index dihitung berdasarkan persentase ovitrap yang positif telur per total jumlah ovitrap yang diamati di Laboratorium Epidemiologi Kesehatan Masyarakat FIKES Unsoed. Kemudian telur ditumbuhkan sampai menjadi nyamuk dewasa, dan diidentifikasi spesiesnya. 


\section{HASIL DAN PEMBAHASAN}

Ovitrap yang dipasang di ketiga desa endemis DBD diambil kembali setelah pemasangan selama 6 hari. Satu ovitrap dipasang di dalam rumah (kamar mandi, kamar tidur) dan satu lagi di luar rumah, dengan batas 5 meter dari rumah. Tidak semua ovitrap yang dipasang dapat kembali Tabel 1. Ovitrap index pada tiga desa lokasi penelitian

\begin{tabular}{lllllll} 
Desa & Posisi & $\begin{array}{l}\text { Ovitrap } \\
\text { teramati }\end{array}$ & $\begin{array}{l}\text { Ovitrap yang } \\
\text { positif telur }\end{array}$ & $\begin{array}{l}\text { Ovitrap } \\
\text { index (\%) }\end{array}$ & $\begin{array}{l}\text { Jumlah total } \\
\text { telur }\end{array}$ & $\begin{array}{l}\text { Jumlah rata- } \\
\text { rata } \\
\text { telur/ovitrap }\end{array}$ \\
\hline \multirow{2}{*}{ Kranji } & Outdoor & 41 & 40 & 97.56 & 1347 & 33.67 \\
\hline & Indoor & 47 & 40 & 85.10 & 1011 & 25.27 \\
\hline Sokanegara & Outdoor & 46 & 34 & 69.38 & 1002 & 29.47 \\
\cline { 2 - 7 } & Indoor & 49 & 25 & 51.02 & 769 & 30.76 \\
\hline \multirow{2}{*}{$\begin{array}{l}\text { Purwokerto } \\
\text { Lor }\end{array}$} & Outdoor & 43 & 36 & 83.72 & 1103 & 30.64 \\
\cline { 2 - 7 } & Indoor & 45 & 29 & 64.44 & 724 & 24.96
\end{tabular}

Berdasarkan hasil ovitrap index di Tabel 1, dari ketiga endemis tersebut OI nya semua di atas 50\% dengan rentang antara $51.02 \%$ sampai $97.56 \%$. OI tertinggi tercatat di Desa Kranji posisi outdoor (97.56\%), sedangkan terendah terlihat di Desa Sokanegara pada posisi indoor (51.02\%). Berdasarkan level OI yang dikemukakan oleh Food and Environmental Hygiene Department, Hongkong, ketiga desa tempat penelitian masuk ke kriteria level 4 (OI di atas 40\%). Rekomendasi aksi yang disarankan pada daerah dengan OI level 4 yakni penggunakan larvasida dan adultisida sangat krusial untuk segera dilakukan untuk bisa menurunkan populasi nyamuk (FEHD, 2017). sesuai jumlah semula, karena ada beberapa ovitrap yang hilang atau tumpah sehingga tidak bisa dilanjutkan untuk diambil ovistripnya. Setelah diambil ovistripnya, telurnya dihitung dengan counter di bawah mikroskup. Hasil ovitrap index pada dilihat pada Tabel 1. 
menjadi perhatian karena dimungkinkan angka kepadatan nyamuknya juga akan tinggi. Kepadatan nyamuk yang tinggi dapat berpotensi untuk menularkan virus dengue. Apabila terdapat penderita DBD di daerah dengan kepadatan nyamuk yang tinggi, potensi untuk dapat menyebar ke sekelilingnya juga tinggi karena adanya vektor yang kompeten (Scott \& Morrison, 2010).

Jumlah rata-rata telur per ovitrap berkisar antara 24.96 sampai 33.67 telur dalam setiap ovitrapnya. Studi yang dilakukan Manica et al (2017) yang memprediksi jumlah rata-rata gigitan $A e$ albopictus betina berdasarkan jumlah ratarata telur menyatakan bahwa adanya peningkatan satu orang yang tergigit dalam setiap penambahan 3 telur dalam ovitrap
(Manica et al., 2017). Dengan rata-rata jumlah telur per ovitrap yang ditemukan di ketiga desa penelitian diharapkan upaya pemberantasan nyamuk harus serius dilakukan. Upaya PSN harus terus digerakkan untuk meminimalisir kontainer yang dapat dijadikan tempat perindukan nyamuk. Hasil ini cukup merepresentasikan status endemisitas ketiga desa yang termasuk desa endemis DBD. Kasus DBD yang terus terjadi setiap tahunnya di ketiga desa tersebut, dan temuan OI yang tinggi seharusnya mencerminkan gambaran hubungan antara kepadatan nyamuk dengan kasus DBD yang terjadi di area penelitian.

Berdasarkan letak ovitrapnya, OI pada posisi outdoor jauh lebih tinggi dibandingkan pada posisi indoor. Detail persentasenya dapat dilihat pada Gambar 1

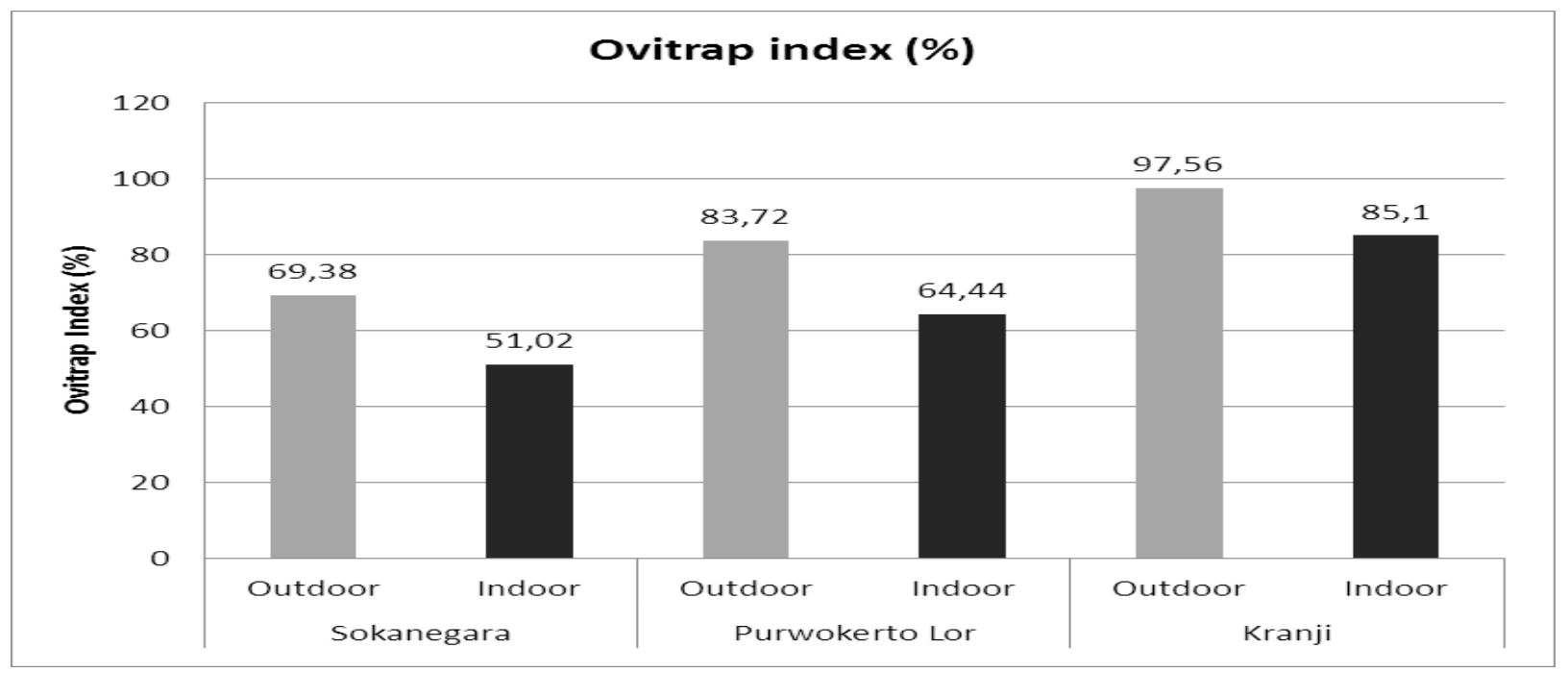

Gambar 1. Ovitrap index di ketiga desa berdasarkan letak pemasangannya 
Berdasarkan Gambar 4, Ovitrap index pada posisi outdoor jauh lebih tinggi dibandingkan pada posisi indoor. Pemasangan ovitrap di luar rumah dilakukan di sekitar rumah sampai batas 5 meter. Ovitrap diletakkan di luar rumah namun tetap terlindungi. Berdasarkan hasil tersebut, dapat dilihat bahwa nyamuk Aedes $s p$ cenderung untuk bertelur di kontainer yang terletak di luar rumah. Hasil ini sejalan dengan penelitian-penelitian yang menyatakan hal yang sama (Getachew et al., 2015; Lee \& Rohani, 2005; Wijayanti et al., 2016). Nyamuk Aedes sp cenderung lebih suka bertelur pada kontainer domestik tetapi juga suka dengan kontainer yang terisi oleh air hujan (Saifur et al., 2012). Berdasarkan penelitian ini, maka perlu diperhatikan kontainer-kontainer di sekitar rumah seperti barang-barang bekas yang berpotensi sebagai perindukan nyamuk. Barang barang bekas di sekitar rumah seperti ban bekas, kaleng bekas, ember yang dapat terisi air saat hujan sangat berpotensi sebagai perindukan nyamuk. Oleh karena itu dengan meminimalisir barang barang bekas di sekitar rumah dapat mengurangi kepadatan populasi nyamuk secara signifikan.

Untuk melihat kasus DBD yang terjadi di desa area penelitian, dikumpulkan data dari Dinas Kesehatan Kabupaten Banyumas. Data yang tercatat pada bulan pelaksanaan penelitian yakni Bulan Agustus sampai Septermber 2016 dapat dilihat pada Tabel 2 berikut :

Tabel 2. Kasus DBD yang terjadi pada saat pemasangan ovitrap di area penelitian

\begin{tabular}{|c|c|c|c|c|c|}
\hline \multirow[t]{2}{*}{ Desa } & \multicolumn{2}{|c|}{ Ovitrap Index (OI } & \multicolumn{3}{|c|}{ Kasus DBD } \\
\hline & & & Agustus & September & Total Tahun 2016 \\
\hline \multirow[t]{2}{*}{ Kranji } & Outdoor & 97.56 & 1 & 1 & 12 \\
\hline & Indoor & 85.10 & & & \\
\hline \multirow[t]{2}{*}{ Sokanegara } & Outdoor & 69.38 & 0 & 1 & 13 \\
\hline & Indoor & 51.02 & & & \\
\hline \multirow[t]{2}{*}{ Purwokerto Lor } & Outdoor & 83.72 & 0 & 0 & 7 \\
\hline & Indoor & 64.44 & & & \\
\hline
\end{tabular}

Berdasarkan Tabel 2, terdapat kasus DBD yang terjadi di Bulan Agustus dan Septmber di Desa Kranji dan Sokanegara. Di Desa Kranji, dimana desa ini mempunyao OI yang tertinggi di ketiga desa penelitian menunjukkan terjadinya kasus DBD 1 kasus di Bulan Agustus dan 1 kasus di Bulan September. Sementara Desa Sokanegara hanya terjadi 1 kasus di Bulan September. Sedangkan untuk Desa Purwokerto Lor , 
tidak terjadi kasus selama Bulan Agustus dan September. Berdasarkan total kasus selama Tahun 2016, di Desa Kranji dan Sokanegara terjadi kasus DBD yang tinggi yakni 12 dan 13, sementara Purwokerto Lor terjadi 7 kasus. Purwokerto Lor lebih sedikit kasus DBDnya walaupun mempunyai OI yang tinggi dibandingkan Sokanegara. Tingkat kepadatan nyamuk memang tidak selalu relevan untuk menggambarkan jumlah kasus DBD di suatu wilayah (Wijayanti et al., 2016). Namun, tentu saja gambaran kepadatan nyamuk di suatu daerah bisa menggambarkan kewaspadaan yang harus dilakukan untuk dapat melakukan upaya pencegahan dan penanggulanngan penularan penyakit DBD.

\section{SIMPULAN DAN SARAN}

Simpulan hasil penelitian ini yakni Ovitrap Index (OI) di ketiga desa yang diteliti cukup tinggi yakni di atas 50\% dengan OI tertinggi pada posisi outdoor di Desa Kranji. OI di ketiga desa masuk ke kategori 4 yang memerlukan pemberantasan seperti larvasida dan adultisida. Aedes sp cenderung lebih suka bertelur di luar rumah, didasarkan pada angka OI yang lebih tinggi di luar rumah. Walaupun tingkat kepadatan nyamuk tidak selalu mencerminkan tinggi rendahnya kasus DBD, namun dapat sebagai gambaran besarnya risiko untuk terjadi penularan kasus DBD. Saran yang bisa diajukan yakni upaya PSN harus terus digalakkan, terutama meniadakan barang barang bekas di sekitar rumah karena nyamuk Aedes sp lebih suka bertelur di luar rumah. Dengan meniadakan kontainer perindukan nyamuk, maka tingkat kepadatan nyamuk di suatu daerah dapat menurun secara signifikan.

\section{DAFTAR PUSTAKA}

Becker, N. P., D ; Zgomba, M; Boase, C ; Dahl, C; Madon, M and Kaiser, A. (2010). Mosquito and Their Qontrol. Hiedelberg: Springer.

Christophers, S. (1960). Aedes aegypti (L). The Yellow Fever Mosquito. Its life history, bionomics and structure. London: Cambridge University Press.

Codeço, C. T., Lima, A. W. S., Araújo, S. C., Lima, J. B. P., Maciel-de-Freitas, R., Honório, N. A., . . . Valle, D. (2015). Surveillance of Aedes aegypti: Comparison of House Index with Four Alternative Traps. PLOS Neglected Tropical Diseases, 9(2), e0003475. doi: 10.1371/journal.pntd.0003475

de Resende, M. C., Silva, I. M., Ellis, B. R., \& Eiras, Á. E. (2013). A comparison of larval, ovitrap and MosquiTRAP surveillance for Aedes (Stegomyia) aegypti. Memórias do Instituto Oswaldo Cruz, 108(8), 10241030. doi: 10.1590/0074-0276130128

FEHD. (2017). Dengue Fever and Vector Surveillance. http://www.fehd.gov.hk/english/safefoo d/dengue fever/ 
Focks, D. A. (2003). A Review of Entomological Sampling Methods and Indicators for Dengue Vectors

Getachew, D., Tekie, H., Gebre-Michael, T., Balkew, M., \& Mesfin, A. (2015). Breeding Sites of Aedes aegypti: Potential Dengue Vectors in Dire Dawa, East Ethiopia. Interdisciplinary Perspectives on Infectious Diseases, 2015, 8. doi: 10.1155/2015/706276

Guzman, M. G., Halstead, S. B., Artsob, H., Buchy, P., Farrar, J., Gubler, D. J., . . . Peeling, R. W. (2010). Dengue: a continuing global threat. Nat Rev Microbiol, 8(12 Suppl), S7-16. doi: 10.1038/nrmicro2460

Higa, Y. (2011). Dengue Vectors and their spatial distribution. Tropical Medicine and Health 39(4), 17-27.

Lee, H., \& Rohani, A. (2005). Transovarial Transmission of Dengue Virus in Aedes aegypti and Aedes albopictus in Relation to Dengue Outbreak in an Urban Area in Malaysia. Dengue Bulletin, 29(106-111), 106-111.

Manica, M., Rosa, R., Della Torre, A., \& Caputo, B. (2017). From eggs to bites: do ovitrap data provide reliable estimates of Aedes albopictus biting females? PeerJ, 5, e2998. doi: 10.7717/peerj.2998

Mustafa, M. S., Rasotgi, V., Jain, S., \& Gupta, V. (2015). Discovery of fifth serotype of dengue virus (DENV-5): A new public health dilemma in dengue control. Med $J$ Armed Forces India, 71(1), 67-70. doi: 10.1016/j.mjafi.2014.09.011

Norzahira, R., Hidayatulfathi, O., Wong, H. M., Cheryl, A., Firdaus, R., Chew, H. S., . . .
Lacroix, R. (2011). Ovitrap surveillance of the dengue vectors, Aedes (Stegomyia) aegypti (L.) and Aedes (Stegomyia) albopictus Skuse in selected areas in Bentong, Pahang, Malaysia. Trop Biomed, 28(1), 48-54.

Pasteur, S. (2016). First Dengue Vaccine Approved in More than 10 Countries. http://www.sanofipasteur.com/en/article s/first_dengue_vaccine_approved_in_m ore than_10_countries.aspx

Saifur, R. G. M., Dieng, H., Hassan, A. A., Salmah, M. R. C., Satho, T., Miake, F., \& Hamdan, A. (2012). Changing Domesticity of Aedes aegypti in Northern Peninsular Malaysia: Reproductive Consequences and Potential Epidemiological Implications. PLOS ONE, 7(2), e30919. doi: 10.1371/journal.pone.0030919

Scott, T. W., \& Morrison, A. C. (2010). Vector dynamics and transmission of dengue virus: implications for dengue surveillance and prevention strategies: vector dynamics and dengue prevention. Curr Top Microbiol Immunol, 338, 115128. doi: 10.1007/978-3-642-02215-9_9

WHO. (1997). Dengue haemorrhagic fever: diagnosis, treatment, prevention and control

Wijayanti, S. P. M., Sunaryo, S., Suprihatin, S., McFarlane, M., Rainey, S. M., Dietrich, I., . . Kohl, A. (2016). Dengue in Java, Indonesia: Relevance of Mosquito Indices as Risk Predictors. PLOS Neglected Tropical Diseases, 10(3), e0004500.

doi: 10.1371/journal.pntd.0004500 